\title{
Korean Celebrity Brand Ambassador as a Strategy to Increase Sales of PT. Shopee Indonesia (Study: “Gfriend” in Shopee 11.11 Big Sale)
}

\author{
${ }^{1}$ Rezki Pratami, ${ }^{2}$ Afrina Sari \\ Magister Ilmu Komunikasi, Universitas Budi Luhur, Jl. Ciledug Raya, Jakarta Selatan, Indonesia. \\ E-mail: 'rezkypratami@gmail.com, ${ }^{2}$ afrina.sari@budiluhur.ac.id
}

\begin{abstract}
This article examines PT. Shopee Indonesia's strategy in increasing sales with Korean celebrity brand ambassadors. Theory used is the integrated marketing communication theory by Kotler \& Armstrong (2008) and brand ambassador concept owned by Rossita \& Percy (2005). Data analysis is with observation, documentation and interviews of 4 informants by applying case study methods. The results showed choosing GFRIEND as the brand ambassador of Shopee 11.11 Big Sale campaign resulted in the sale of 70 million items sold on November 11, 2019, and sales tripled in the first hour compared to 2018. By running four of eight integrated marketing communication models by Kotler \& Armstrong (2008) such as sales promotion, advertising, interactive marketing, and also events and experiences conducted through both mass media, online media, and social media resulted in a third quarter achievement of 2019 PT. Shopee Indonesia increased by 261,1\% or equivalent to 257,2 million dollars, as well as Gross Merchandising Value (GMV) of 69,9\% or equivalent to 4,6 billion dollars compared to 2018. This means that making GFRIEND as a brand ambassador Shopee 11.11 Big Sales is the right strategy and successfully brings PT. Shopee Indonesia to a significant increase in sales.
\end{abstract}

Keywords: Brand Ambassador, Strategy, E-commerce, PT. Shopee Indonesia, Marketing Communication.

\section{INTRODUCTION}

The phenomenon of business and commerce in the digital age, offers a variety of lines that are already integrated with internet technology. Globalization is touted as the cause of the birth of a change in the style of commerce from conventional to digital. In order to maintain existence, a company or entity should follow the trends of the digital trading industry. McKinsey in cnn.indonesia.com (2019), the digital trading industry in Indonesia became an increasingly popular business in 2019. The penetration of Indonesian online shopping increased by about $9 \%$ compared to 2017 and then to $83 \%$ of the accumulated internet users in Indonesia.

E-commerce is one of the online shopping platforms that people love most because of its easy access and diverse choices. Harahap (2018), e-commerce or online shopping is a buying and selling activity or transactions conducted with intermediaries in the form of social networks or online shopping sites. Online shopping activities are carried out through manufacturers or resellers using internet technology, payment is made by bank transfer, virtual account as well as cash on delivery (COD), and finally the goods will be delivered with the agreed delivery service.

E-commerce or online shopping is a process of buying and selling products electronically or online with the intermediary of business transactions in the form of computerization with internet media. Hidayat (2008:7) highlights the 
advantages of e-commerce components compared to conventional, namely; (1) there are many products that can be marketed in e-commerce sold through online shopping, (2) where selling products is internet means must have a domain, (3) the receipt of messages is done virtually i.e. by e-mail, sms, or telephone line, (4) has a varied payment method namely debit and transfer, credit card, even cash, (5) has customer service to assist in transactions, (6) the method of delivery is done with the agreed delivery service. E-commerce is differentiated into five types based on how the transaction type is. Laudon (2008:63) classifies types of e-commerce, namely; Business to Consumer (B2C) is a company to consumers, Consumer to Consumer $(\mathrm{C} 2 \mathrm{C})$ namely consumers to consumers, Business to Business (B2B) companies to businesses, Peer-toPeer (P2P) i.e. online loan transactions from borrowers to investors, and Mobile Commerce (M-Commerce) i.e. transactions by relying on mobile phones between customers and business provider organizations. In research conducted by Global Web Index (2019) explained that Indonesia is the country with the highest e-commerce or online shopping users in the world. $90 \%$ of internet users between the ages of 16 and 64 reported buying products online as stated in this following FIGURE 1.

According to the report data from iPrice cited in katadata.co.id (2019), Shopee is listed as the most popular e-commerce in Southeast Asia during the second quarter of 2019, in application activity, number of downloaded applications, and transactions in regional markets. The value of Shopee transactions increased by $72.3 \%$ to 54 Trillion rupiah, compared to 42 Trillion rupiah in 2018. Based on data released by mobile app analytics company AppAnnie.com (2019), shopee indonesia app in iOS downloads gets a rating of 4,5 or 258 ratings, while in android downloads get a rating of 4,6 or 5206713 ratings. AppAnnie also reported that Shopee is the number one app based on downloads and average monthly active users in the Shopping category in Southeast Asia and Taiwan for the second quarter in a row. This was strengthened by Shopee's leadership in Indonesia by ranking first by MAU (Monthly Active User) in the Shopping category and recording 138 million orders for the third quarter of 2019.

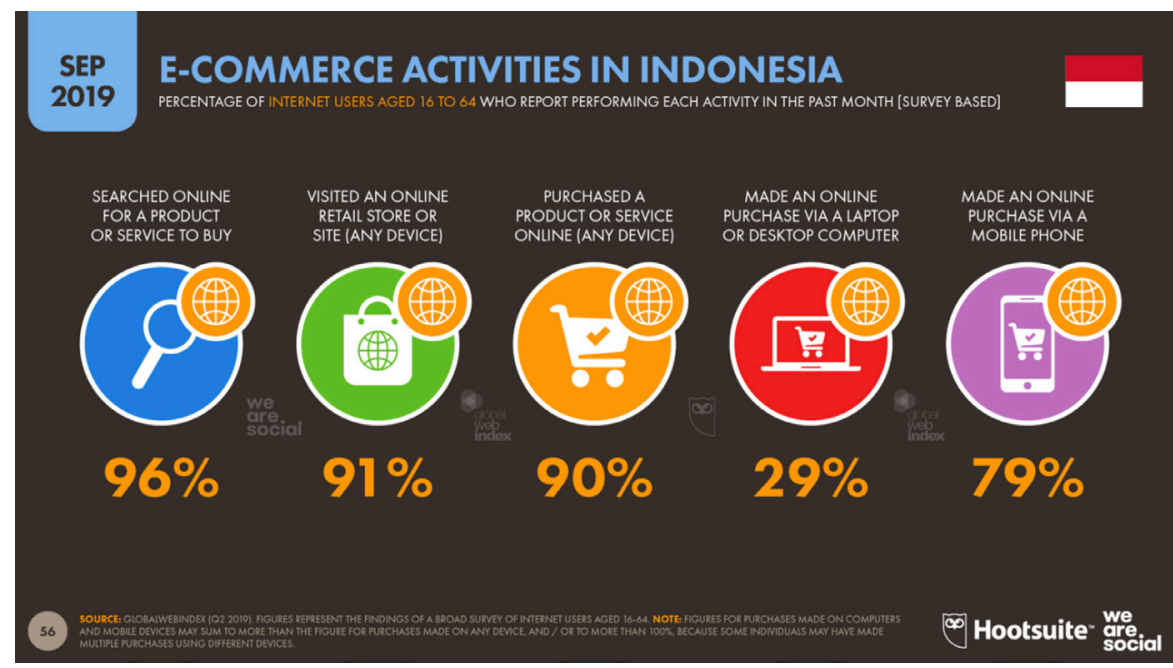

FIGURE 1. E-Commerce Activities In Indonesia

Source: https://datareportal.com/reports/digital-2019-ecommerce-in-indonesia 
According to the report data from iPrice cited in katadata.co.id (2019), Shopee is listed as the most popular e-commerce in Southeast Asia during the second quarter of 2019, in application activity, number of downloaded applications, and transactions in regional markets. The value of Shopee transactions increased by $72.3 \%$ to 54 Trillion rupiah, compared to 42 Trillion rupiah in 2018. Based on data released by mobile app analytics company AppAnnie.com (2019), shopee indonesia app in iOS downloads gets a rating of 4,5 or 258 ratings, while in android downloads get a rating of 4,6 or 5206713 ratings. AppAnnie also reported that Shopee is the number one app based on downloads and average monthly active users in the Shopping category in Southeast Asia and Taiwan for the second quarter in a row. This was strengthened by Shopee's leadership in Indonesia by ranking first by MAU (Monthly Active User) in the Shopping category and recording 138 million orders for the third quarter of 2019.

Things that e-commerce platform content service providers do to increase sales, one of the things that can be unavoidable and trivial is to choose a brand ambassador or product ambassador who can bring a brand to be more recognizable, get more attention from consumers, until getting the final result is achieving good sales. Raswen (2019) Brand Ambassador is important in the sustainability of a company. Through brand ambassadors the company gives the trust of the audience or consumers, as well as a tool to communicate a product that is ultimately able to form the identity of the company. While Shimp in Noviyanti (2017) brand ambassador is a star that represents a product that wants to be advertised. A company will conduct star selection as a brand ambassador capable of bringing the company to a reputation for quality, marketing reputation, and product innovation.

Shimp (2003) mentions brand is a design in the form of names, signs, and abbreviations that are able to identify a product and differentiation for another product. A good brand will have the power so that it is formed always in the consumer's mind and easy to remember. Kotler (2008), while Ambassador, is a person or entity often associated with public figures or celebrities who have a major influence on the world. This figure is believed to psychologically have the power to influence one's beliefs and attitudes towards the products presented. From the above understanding, it can be concluded that the brand ambassador is an individual body born of celebrities or public figures who have the power to convince the psychological person with the brand presented, so that it is inherent in the mind of the consumer. Brand ambassadors are usually chosen based on the characteristics of a product that it will bring and adjust to the target market so that it is able to represent a product and have a good selling value.

Rossiter and Percy in Royan (2005:15), divided the characteristics of the brand ambassador as follows; (1) Visibility, popularity in a public figure chosen as a brand ambassador must be very inherent, because it leads to how well known from the perception of the wider public, (2) credibility, is the background of culture, experience, and psychological in perceptions formed by communicators influenced by five senses, (3) attraction, a brand ambassador both has the appeal of physical charm and personality in order to be able to amaze viewers and consumers , (4) power, power is able to increase the intensity of the purchase, because it is appropriate to instruct the consumer to show his or her likeness and perform the purchase action.

After briefly partnering with 
BLACK PINK in 2018 as Brand Ambassador, 2019 Shopee officially announced that Christiano Ronaldo will be his newest Brand Ambassador. The two names cannot be trivialized. Both have an image that can represent a product to be in demand, because the level of fans with a number is quite fantastic in Indonesia. Larasati (2019) in an online article page explaining Shopee Indonesia Director Christin Djuarto said Christiano Ronaldo was able to attract a high level of interest from both men and women. Two angle is obtained at once for female consumers because of his good-looking, for male consumers because he is a world legend footballer. This is a very satisfactory result because it is able to boost sales during September 2019.

Aria in katadata.co.id (2018) released data that Shopee managed to break the new sales record in the campaign event 12.12 Birthday Sale in 2018 which was 12 million transactions in 7 countries, and Indonesia accounted for 5.4 million total transactions and was the most compared to other Countries. In the event, shopee app was successfully visited by more than 48 million users, supported by 450 thousand brands and sellers as well as 60 million promos. Goyang Shopee was successfully played 46 million times, while Shopee Quiz was able to be followed by 11 million participants from 7 Asian countries. Girl Band from Korea BLACKPINK, successfully brought Shopee in sales with a fantastic number of sales, even successfully made Shopee as the number one e-commerce platform in Indonesia beating Lazada (FIGURE 2).

Every month Shopee campaigns to optimize sales. Through campaigns, Shopee often presents top stars from home and abroad. One of the next stars is Celebrity and Girl Band from Korea GFRIEND, which is also a Brand Ambassador in Shopee Korean Fair campaign period August to December 2019. This is certainly not without reason, according to Heppiana (2019) including Korean elements (Korean Wave) in Shopee campaigns is important to consider. Through Korean drama, movies, as well as music is a phenomenon of Korean Wave that is currently widely used by companies, in hopes of getting good feedback from consumers. In accordance with the above, the marketing communication activities of a company namely PT. Shopee Indonesia takes place and happens. There are two components of science in marketing communication, namely communication science and marketing science. Communication is the process of delivering messages from communicators to communion in order to be able to get feedback in the form of behaviour. Marketing in this case is to offer a product to consumers as its target. Marketing communication is a way and process of conveying a message from a

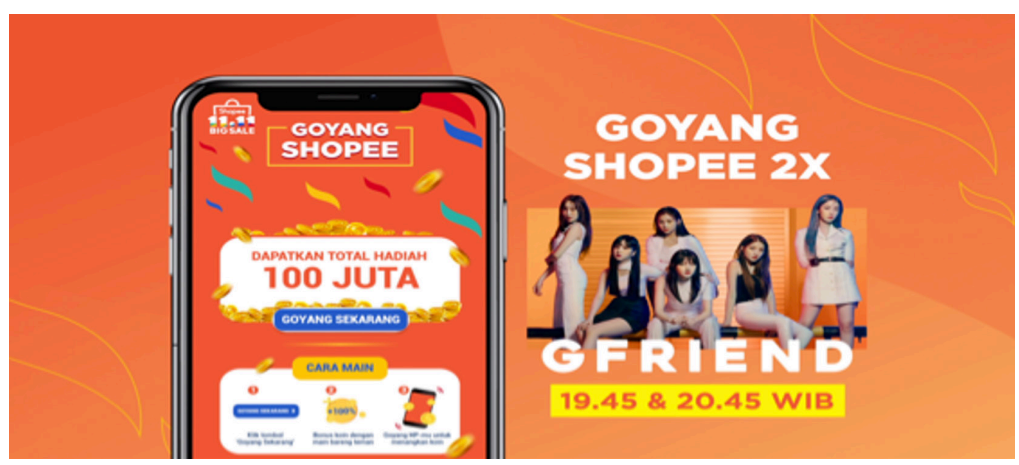

FIGURE 2. Goyang Shopee Promotion Shopee 11.11 Big Sale GFRIEND

Source: Tomy Sukowati, Senior Associate Animator - PT. Shopee Indonesia 
person to his target by persuading and wooing to be offered a product in the form of goods or services. (Maria Fitriah, 2018:5). With the communication process, the marketing process can be carried out properly and perfectly. Communication makes knowledge exchange relationships work perfectly on marketing. Therefore, it takes good knowledge from a communicator in order to do the bidding and bidding on a product in the form of goods and services so that there is a desire to buy.

The purpose of marketing communication is to get feedback in the form of responses and responses from potential consumers that include; (a) cognitive, i.e. knowledge, (b) affective, i.e. a person's tendency to show a sense of attraction to something offered, (c) conative, i.e. an action-to-buy behavior, (Tjiptono, 1997). While Kotler \& Keller (2007:204), mention the purpose of marketing communication is to contribute to brand equity by building brand awareness that is always in the memory by making a good image of the brand. The success of marketing communication is how a company is able to create a good brand awareness on a product that wants to be marketed so that this product is always the top of mind among consumers.

Gita \& Setyorini (2016) explained the level of relationship between brand ambassador and brand image is a unity that goes hand in hand. a successful brand ambassador will give birth to a brand image that will be attached to the consumer's head. thus a company can make a brand ambassador as a communication strategy in conveying the sponsorship message contained by a brand. A communication strategy allows a communication action to be taken for communication targets designed as targets for change. That in the marketing communication strategy, the main target is first, how to make people realize that they need a product, service or value and when attention has been awakened, then the most important target is for a loyal person to buy that product, service or value (Bungin, 2015: 62).

Wanting to repeat the success when presenting Korean celebrity Girl Band BLACK PINK in 2018, Shopee also brought GFRIEND as Brand Ambassador to Indonesia. GFRIEND also enlivened TV Show Shopee 11.11 Big Sale which was broadcast live on several private TV stations of the country. This is also done as one of the embodiment at the request of GFRIEND fans in Indonesia. Previously, GFRIEND had greeted fans through shopee live streaming on August 17, 2019, live from South Korea. Based on the above description, the author will describe two important things of the research namely; how integrated marketing communication PT. Shopee Indonesia and how "GRFIEND" as Korean celebrity brand ambassador is implemented as a strategy to increase sales PT. Shopee Indonesia in 11.11 Shopee Big Sale campaign.

\section{METHOD}

This research with the title Korean celebrities Brand Ambassador as a strategy to increase sales of PT. Shopee Indonesia focuses on the study of the Korean Girl Band GFRIEND in Shopee 11.11 Big Sale, using a case study research method by applying a descriptive qualitative approach and a constructivist paradigm. Qualitative as a method that provides up-to-date information so that it can provide benefits to science and is able to provide solutions to the description of various problems. According to Mulyana in (Ramadhan, 2019) it is explained that case studies are comprehensive descriptions and explanations of various aspects of an individual, a group, an organization (community), a program or social situation.

This research was conducted by 
interviewing four informants as research subjects, namely Riyan Singgih Nasution as Public Relations - Marketing, Mahartian as Senior Associate Brand Marketing, Tomy Sukowati as Senior Associate Animator and Hamdya Jaka as Videographer of PT. Shopee Indonesia as an informant. The object of research is Brand Ambassador GFRIEND in Shopee 11.11 Big Sale.

Data collection techniques to be done through interviews, observations and documentation are supported by the data processing process using triangulation techniques. According to Sugiyono (2013:330) triangulation is defined as a data collection technique that combines data from various data collection techniques and existing data sources. The validity of data in qualitative research is one of the very important parts to know the degree of trust of the results of the research that has been done using triangulation techniques in data collection, then the data obtained will be more consistent so that it becomes a valid and accountable data. (Maskhun Fauzi, 2019)

The theory used in this study is Kotler and Keller's integrated marketing communications. Kotler and Armstrong (2008:120), Integrated Marketing Communication (IMC) is the activity of associating or integrating various marketing activities by using various mediums to convey a consistent and interesting message about their products and companies/ organizations. A good marketing communication process will have implications for positive trust in the brand, so that the terraced marketing communication can run according to the plan. According to Kotler and Keller (2008) stated that integrated targeting communication is a marketing communication plan that recognizes the added value of a comprehensive plan that evaluates the strategic role of various communication disciplines to provide maximum clarity, consistency and impact through the seamless integration of various messages. From the above definition it can be concluded that integrated marketing communication is a marketing communication planning that integrates and evaluates strategically within a company. The integrated marketing communication mix according to Kotler and Keller (2008) consists of: 1. Sales Promotion 2. Public Relations (Publicity) 3. Advertising 4. Direct Marketing 5. Personal Selling 6. Interactive Marketing 7. Events and experiences 8. Word of mouth marketing.

\section{RESULT AND DISCUSSION}

In this section, the researcher will describe the research, namely the results of interviews related to theories and concepts. Which has been described in the previous chapter. The researcher will present the essence of the research results obtained regarding Korean Celebrity Brand Ambassador as a Strategy to Increase Sales of PT. Shopee Indonesia (Study of Girl Band GFRIEND in Shopee 11.11 Big Sale).

\section{Korean Celebrity Brand Ambassador “GFRIEND" PT. Shopee Indonesia}

Shopee is an ecommerce platform that made its debut in 2015 and is headquartered in Singapore. Shopee is part of the famous Games company, SEA Company. Since its emergence in the digital marketing industry for ecommerce platforms, Shopee has expanded its business to various countries namely Malaysia, Thailand, Vietnam, Philippines and Indonesia. By providing shopping services that make it easy for customers to get what they want, Shopee guarantees easy, secure, and flexible shopping facilities with payments that can now be made not only by transfer, but also provided by COD or Cash on 
Delivery services. Shopee is the leading ecommerce platform in Southeast Asia and Taiwan, as it successfully stores online shopping containers that are able to meet the needs of markets throughout Southeast Asia. Various products are brewed, ranging from household needs, baby and child needs, fashion, gadgets, electronics, care and health, equipment byraga and many more. Shopee is not the first in Indonesia, but Shopee is able to become the number one online shopping company in Indonesia. (Riyan Singgih Nasution, Public Relations - Marketing PT. Shopee Indonesia, 2019)

As an e-commerce-based company, PT Shopee continues to strive in developing its business in the field of marketing communication. This company is notabene not a company from Indonesia, doing various ways to be able to get the attention of consumers. The purpose or goals of marketing communication are to obtain 3 psychological effects, namely cognitive, affective, and concative effects. Where cognitive effects are consumer knowledge, the affective effect is a consumer's sense of interest in the program or product offered, and the concative effect of the action to buy. No matter how much effort is made, when a company has fulfilled the purpose of marketing communication, the next goal is to be a loyal consumer or will repurchase in the same place, namely PT. Shopee Indonesia.

Based discussed in the literature review explanation about brand ambassador, brand ambassador serves to bring good name and company image so that the company profit materially. The selection of brand ambassadors in a company that is co-owned by divisions related to various considerations. Based on Rossiter and Percy in Royan (2005:15) the characteristics of the brand ambassador have many considerations, such as visibility, credibility, attractiveness,

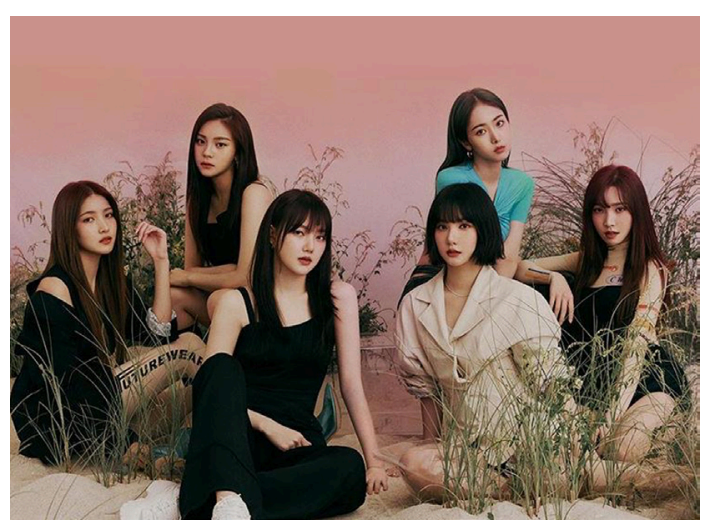

FIGURE 3. Girl Band GFRIEND on

Social Media Instagram

Source: Instagram @gfriendofficial

power to appeal to consumers. PT. Shopee Indonesia chose korean celebrities and Girl Band "GFRIEND" as brand ambassadors in Shopee Korea Fair and Shopee 11.11 Big Sale campaigns, for certain reasons that had previously been agreed as seen from FIGURE 3.

Visibility or popularity, such as his previous experience with Korean celebrities BLACK PINK in the 2018 campaign and achieved success at that time, made PT. Shopee Indonesia wants to repeat that success by bringing in other Korean celebrities. Especially the level of popularity of Korean celebrities is in the wind especially for indonesians, especially GFRIEND as seen. GFRIEND's

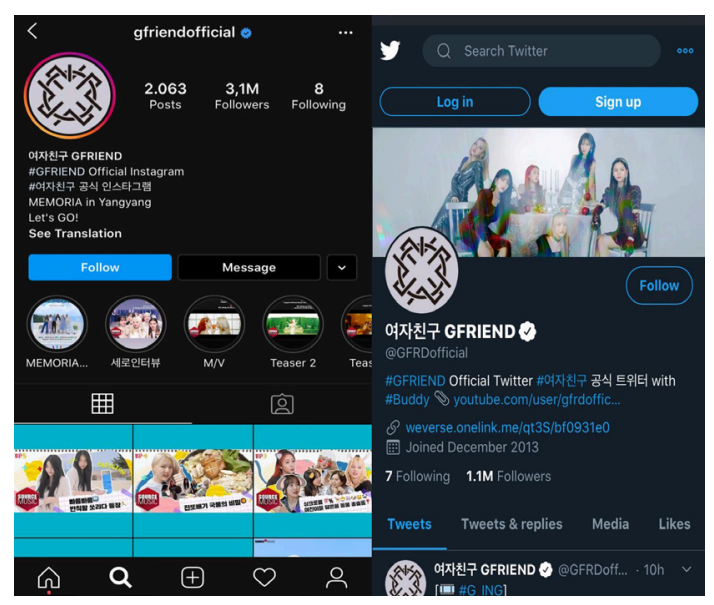

FIGURE 4. Social Media GFRIEND Source: Instagram @gfriendofficial and Twitter@GRFDofficial 
popularity in Indonesia is seen in the number of followers on Instagram @ gfriendofficial social media as much as 3,1 Million followers, and followers on social media twitter@GFRDofficial as much as 1,1 Million followers, it can be seen from FIGURE 4. That number is not a small amount, that number should be taken into account regarding the level of popularity of GFRIEND in Indonesia. (Tomy Sukowati, Senior Associate Animator - PT. Shopee Indonesia, 2019).

Korean trends that are currently in demand of Indonesian millennials are utilized by Shopee as an e-commerce company whose average consumer is millennial. The market segment in Indonesia is quite potential for K-Pop fans. Bringing GFRIEND to Indonesia On the basis of the enthusiasm of indonesian fans, Shopee brought GFRIEND to Indonesia and made as a brand ambassador in the Campaign Shopee Korean Fair and Shopee 11.11 Big Sale, in hopes of getting an equally greater opportunity when bringing BLACK PINK to Indonesia 2018. This moment is also used for Shopee as a strategy to be able to get consumer quantity that is able to reach the target.

Furthermore credibility or credibility, GFRIEND as a Korean celebrity who has a career as a Girl Band is a celebrity with a good y ang record. Born and formed in 2015, GFRIEND present in singing world with a number of works namely 8 singles, 2 studio albums, 7 mini albums, 17 soundtrack songs, and 17 music videos. GFRIEND also starred in a number of reality series as many as 8 titles throughout 2015 to 2019 , then 27 TV shows, and 3 drama titles. GFRIEND has performed concerts in several countries in Asia including Indonesia from 2018 to 2019 as many as 21 times with the theme GFRIEND 1st Asia Tour: Season of GFRIEND, GFRIEND Spring Tour in Japan 2019 Bloom, GRIEND 2nd Asia Tour 2019: Go Go Friend!. As well as getting several awards namely Best News Female Artist at Melon Music Award 2015, "Rough" Song of The Year 2017, and 29 total most wins in the space of 1 year.

The above data shows that GFRIEND is an Unquestioned Korean celebrity both talented or fans, as well as a reputation for achievement. This makes Shopee confident that good credibility in GFRIEND can bring good results when made as a Brand Ambassador. The third characteristic is attraction or attraction, a number of achievements owned by GFRIEND can be used as an attraction for fans. Contrary to achievements, the 6-member GFRIEND has beautiful look, and is able to attract anyone who has the charm especially if the audience is a K-Pop fan.

Lastly is power or power, the high level of fan is offset by the amazing achievement of making GFRIEND as a korean celebrity has a good place for fans and this mapu be used as a power. Shopee sees GFRIEND as having excellent power if balanced or synchronized with shopee's target consumer market, so that later Shopee can be the market leader in the world of market place or e-commerce, especially in Indonesia. (Mahartian, Associate Brand Marketing - PT. Shopee Indonesia, 2019)

\section{Implementation of Integrated Marketing Communication brand ambassador "GRIEND" with PT. Shopee Indonesia}

Competition between e-commerce industries is increasingly intense, making Shopee Indonesia's marketing communication strategy different and bolder than others. Ininterviews conducted by three speakers from different fields, namely; Mahartian as Associate Brand Marketing, Tomy Sukowati as Senior Associate Animator and Hamdya Jaka as 
Videographer PT. Shopee Indonesia, an integrated marketing model conducted by PT. Shopee Indonesia based on Kotler and Keller theory (2008) namely; sales promotion, advertising, interactive marketing, and event \& experience.

The first integrated marketing communication model is Sales Promotion. As mentioned in the discussion of social marketing, that as one of the strategies to get consumers is to provide promotion of various sales programs. In shopee korean fair and Shopee 11.11 Big Sale campaign with GFRIEND brand ambassador, Shopee presents various promotions to achieve sales targets in welcoming the peak night of Shopee 11.11 Big Sale held throughout the week of October 3rd to November 10th, 2019. Sales promotions provided by Shopee include; 2 times shake Shopee with iPhone 11 and Toyota Yaris Car, 2 times Shopee Catch with Honda CBR Motorcycle and Honda HRV Car, 1 time Shopee Potong with Home Theather and Smart LED TV Samsung, Shopee Quiz with sensational celebrity host Nikita Mirzani, Flash Flash Flash Rp. 99, and Brand Big Sale which is discounted for some suitable products up to $80 \%$.

The next promotion is a special promotion given on November 10, 2019 in the 11.11 Big Sale campaign with GFRIEND, which is also the peak night of Harbolnas (national shopping day)
TV Show Shopee 11.11 Big Sale. The promotions given to the audience or consumers are namely; Free Shipping minimum spend Rp. 0, Cashback 111\%, 6 times Flash Sale Kilat Rp. 99, Shopee Tangkap with total prize worth Rp. 650 Million, Collection only by paying $11 \%$, Collection Discount 50\%, and Special Collection All 10 Thousand.

Advertising is an important component of marketing. One of the models of IMC (integrated marketing communication) by advertising or promoting a product in the form of goods and services to consumers. In accordance with the true meaning of advertising is an idea, an idea, in the form of a combination of narrative, audio, visual and animation produced to convey the message and promote a goods and services in order to gain the trust of consumers and be made purchases by consumers. The promotion that is done in advertising is using media, media that is intended to be traditional media, mass media, or even digital-based media. The advertising media specified by the ad communicator will be adjusted to who the target market is.

As a digital-based e-commerce platform, advertising on digital media is an important thing to do and work with ideas and ideas that are demanded always unique, new, and fresh, in order to attract the attention of the audience and make that audience as consumers especially

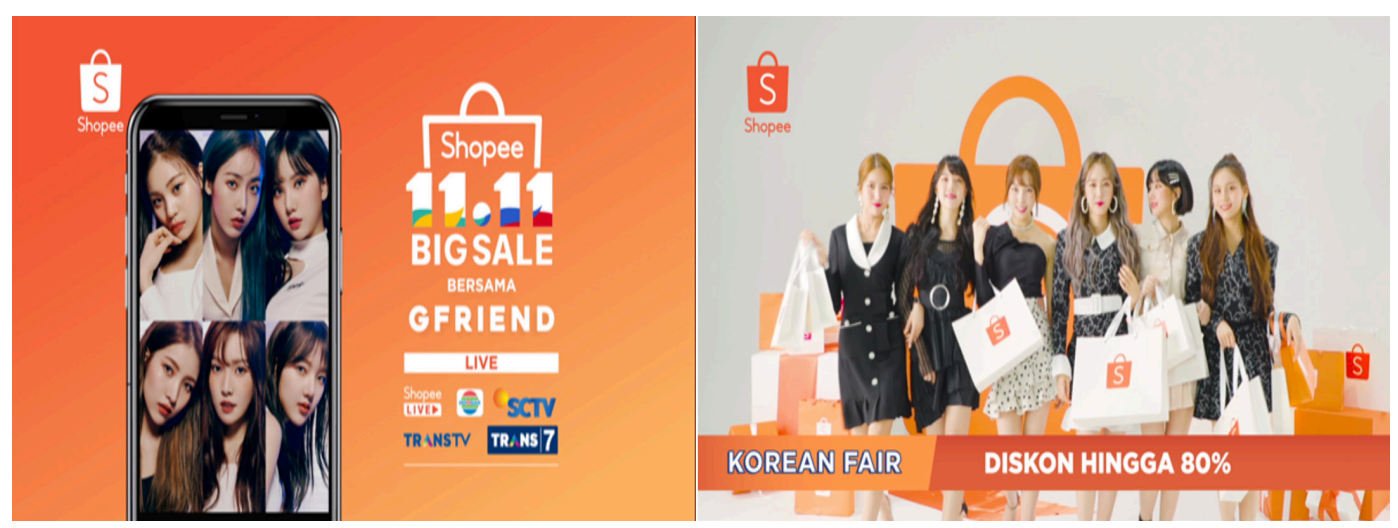

FIGURE 5. Shopee 11.11 Big Sale Korean Fair TVC

Source: Tomy Sukowati, Senior Associate Animator - PT. Shopee Indonesia 


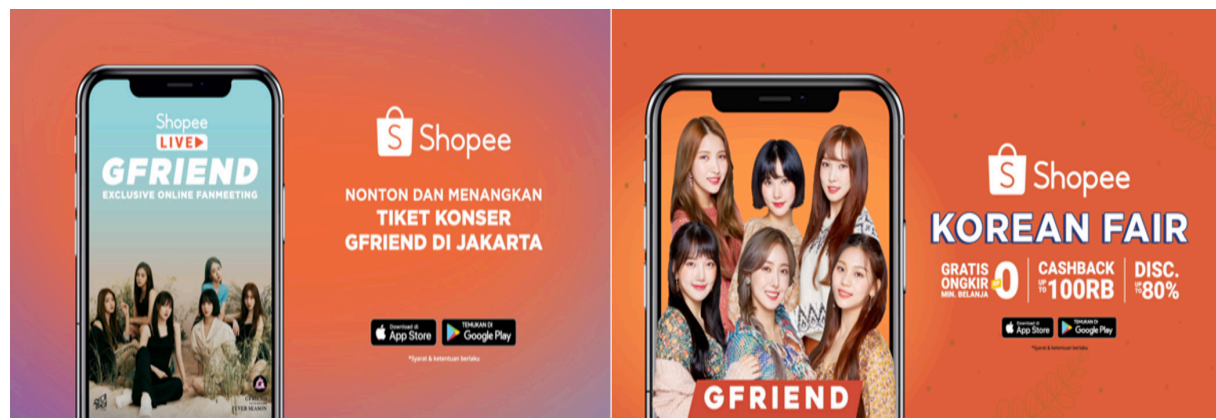

FIGURE 6. Shopee Korean Fair Media Digital Ads

Source: Tomy Sukowati, Senior Associate Animator - PT. Shopee Indonesia

with GFRIEND Brand ambassador as the implementation of integrated marketing communication PT. Shopee Indonesia on Korean Fair and Shopee 11.11 Big Sale campaign as seen from FIGURE 5.

In digital media, Shopee promotes advertisements on various media lines, such as on the shopee.id website or Shopee Indonesia app, on Instagram social media on an official account or official @ Shopee_id account that will inform you what promotions are and will be done. Not only on Shopee's official Instagram account, Shopee's ads on Instagram are also posted on Instagram stories and feeds from some of the supporting artists in the campaign. There are also ads that will always appear on youTube social media that are randomly aired but have been adjusted to certain airtime. Other social media done as media advertising Shopee namely facebook and twitter. Some news portals and other internet media are also used as a medium of shopee ad serving, both in the form of banner ads, pop up ads, classified ads and much more. The $\mathrm{ad}$ in question here, is further divided into two parts, namely ads with moving visual animations and motionless ads that are only in the form of logos that characterize Shopee. (Tomy Sukowati, Senior Associate Animator - PT. Shopee Indonesia, 2019).

Furthermore the third communication model is public relations or public relations. Public relations conducted by PT. Shopee Indonesia in the campaign 11.11 Big Sale and Shopee Korean Fair with Brand is presenting GFRIEND in Shopee Live involving gfriend fan community with the name Buddy from Indonesia which was held on August 17,2019 at 13.00 WIB as seen from FIGURE 6 and FIGURE 7. This is done as a stategis step to "check the waves" that Shopee did before later GFRIEND will be

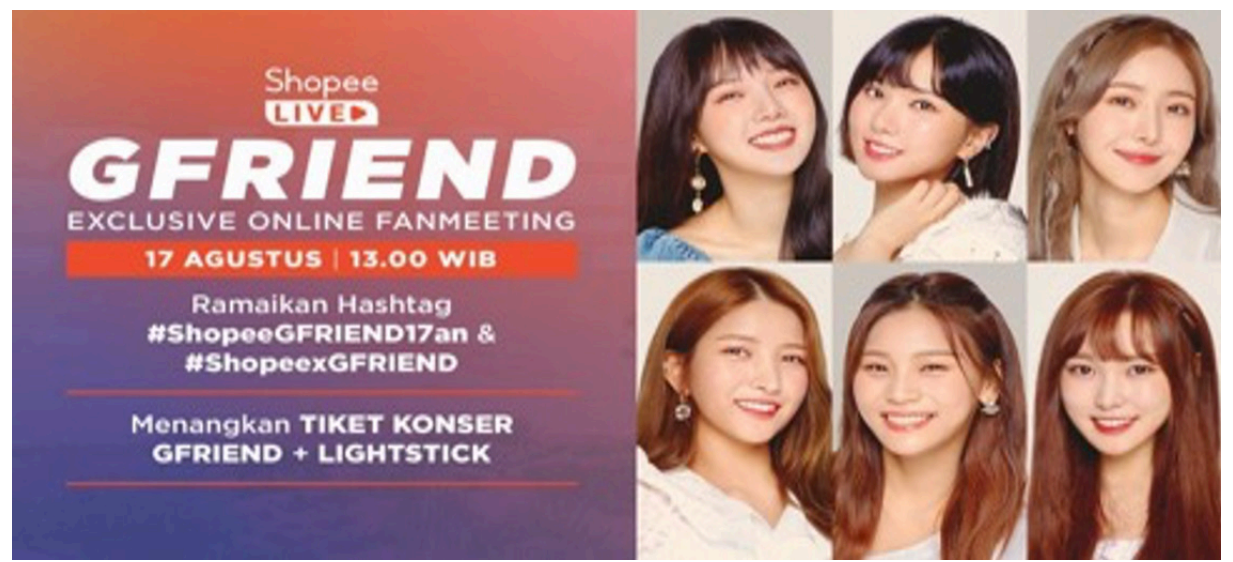

FIGURE 7. Shopee Live GFRIEND as Interactive Marketing Source: https://twitter.com/shopeeid/status/1162265947253555201 


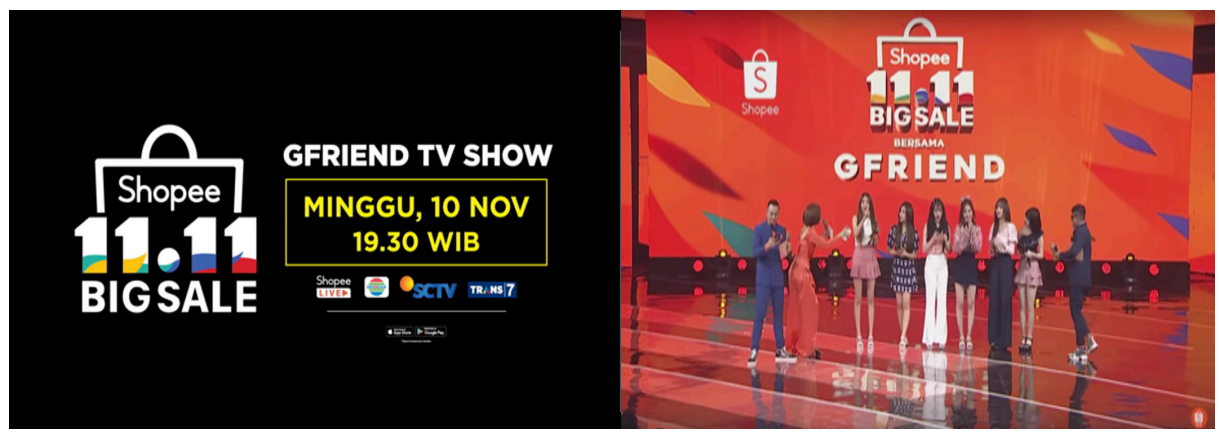

FIGURE 8. Shopee 11.11 Big Sale GFRIEND TV Show

Sumber: Tomy Sukowati, Senior Associate Animator - PT. Shopee Indonesia

actually presented at the peak of TV Show 11.11 Big Sale. Shopee live GFRIEND can be watched directly through mobile apps on smart phones, and Shopee also provides a means to watch a party held in Kota Kasablanka Mall that involves a community of lovers of GFRIEND or Buddy Indonesia. GFRIEND will communicate directly through the event and answer all questions asked through social media twitter, Instagram, and facebook. Public relations are important aspects that must be considered in order to achieve sales targets, by engaging the public directly in marketing activities.

The latter's integrated marketing communication model is events and experiences. Shopee 11.11 Big Sale TV Show is the culmination of a promotional campaign conducted throughout the $3 \mathrm{rd}$ week of October to November 10, 2019. This event was enlivened by various stars of the country and GFRIEND as special guests. The show was broadcast live on a number of national televisions such as Indosiar, SCTV, Trans TV and Trans 7, sunday 10 November 2019 at 19.30 WIB.

Hosted by Andika Pratama, Ramzi, and Astrid Tiar, the 11.11 Big Sale TV Show wowed audiences with a number of cast members to enliven such as Syahrini, Noah, Via Vallen, Bunga Citra Lestari, Hotman Paris, Gisel \& Gempi, Nicholas Saputra, Didi Kempot, Ayu Tingting, Maia Estianty and many more as seen as Figure 8. Another thing in the integrated marketing communication model of events and experiences is live streaming with a total duration of 27 hours nonstop. As well as collaborating on Goyang Shopee Promotion which also involved GFRIEND as the main star and totaled hundreds of millions of rupiah as a gift that has been prepared for the audience participating in the promo as seen from FIGURE 8.

The purpose of creating this event is to give a different impression and shopping experience by providing entertainment and excitement with various promotions and gifts that have been prepared, so that consumers remain loyal to Shopee and only choose Shopee as an e-commerce platform. Another goal is for Shopee to be able to achieve the sales targets that have been determined to be the leading market place and credible.

The purpose and utilization of Korean celebrity Brand Ambassador GFRIEND as a strategy in increasing $\mathrm{pt}$ sales. Shopee Indonesia in korean fair campaign and Shopee 11.11 Big Sale successfully achieved. This is evidenced in the sales data that was successfully compiled by PT Shopee Indonesia, that there were 70 million total goods sold on November 11, 2019, the figure doubled in one hour compared to November 11, 2018. Shopee Capture in Shopee games which is Shopee's first Augmented reality feature was successfully played more than 150 million times in the 11.11 big Sale campaign that lasted for 25 days.

Brands and sellers in Shopee 
achieved the best deals on November 11, 2019. The highest performing brands recorded an 11,000-fold increase in average visits with 5,000 booking growth, and the most shopping activity was at 13.00 WIB. The most popular brands in the 11.11 Big Sale are Unilever, Maybelline, Realme, Xiaomi, Elzatta, and Terry palmer. For the most selected product categories are Beauty, Home \& Living, Woman Clothes, Mobile \& Accessories, and Muslim Fashion. For the best-selling products are Nestum Choco Polybag, Xiaomi Redmi Note 8 Pro, Realme e, Pepsodent Toothpaste. And the most active areas in purchasing are West Java, Jakarta and East Java. (Riyan Singgih Nasution, Public Relations Marketing PT. Shopee Indonesia, 2019)

During the period of 2019 , in the third quarter of PT. Shopee Indonesia showed strong growth. Shopee is the number 1 app based on downloads and the average monthly active user in the Shopping category in Southeast Asia and Taiwan for the second quarter in a row, according to App Annie. Shopee also strengthened its leadership in Indonesia by ranking first by MAU (Monthly Active User) in the Shopping category and recording 138 million orders for the quarter.

Through a number of promotions conducted by PT. Shopee Indonesia by partnering with a well-known brand ambassador is the right jsaha in scoring good achievements in the world of e-commerce in Indonesia. Other achievements that PT. Shopee Indonesia is experiencing a YoY (Year of Year) increase of $261.1 \%$ or equivalent to an increase in profit during the third quarter of 2019 of \$257.2 million, a significant increase from the third quarter of 2018 which earned a total profit of $\$ 71.2$ million. In the third quarter of 2019 , PT. Shopee Indonesia also recorded an increase in GMV (Gross Merchandising
Value) which originally (third quarter 2018) was at 2.7 billion dollars rising to 4.6 billion dollars or up by $69.6 \%$. From this result brings PT. Shopee Indonesia became the first ranked e-commerce even beating Tokopedia and Lazada in the third quarter of 2019. It means, making Korean celebrity GFRIEND as Shopee brand ambassador especially in Shopee 11.11 Big Sale campaign, especially in the promotion of Shopee Korea Fair campaign, is the right thing has done with the results of a significant achievement record.

\section{CONCLUSION}

Based on analysis conducted with social marketing communication, brand ambassador and integrated marketing communication on GFRIEND as korean celebrities utilized pt. Shopee Indonesia as a strategy to increase sales through Shopee Korean Fair and 11.11 Big Sale campaigns, resulting in the following conclusions: (1) PT. Shopee Indonesia conducted in-depth research before griend as brand ambassador using 4 methods namely determining popularity, credibility, attractiveness, and power. In this case GFRIEND meets 4 shopee brand ambassador selection methods with the aim of increasing the number of sales. GFRIEND is always involved in every promotion that has been on the network in Shopee 11.11 Big Sale. (2) By running four of eight integrated marketing communication models by Kotler \& Armstrong (2008) such as sales promotion, advertising, interactive marketing, and also events and experiences conducted through both mass media, online media, and social media resulted in a third quarter achievement of 2019 PT. Shopee Indonesia increased by $261.1 \%$ or equivalent to 257.2 million dollars, as well as Gross Merchandising Value (GMV) of $69.9 \%$ or equivalent to 4.6 billion dollars compared to 2018 . This 
means that making GFRIEND as a brand ambassador Shopee 11.11 Big Sales is the right strategy and successfully brings $\mathrm{PT}$. Shopee Indonesia to a significant increase in sales.

\section{REFERENCES}

Agung. Bintoro (2019). Tren Positif Shopee Berlanjut, Kini Salip Jumlah Pengguna Aktif Tokopedia di Indonesia. https://dailysocial.id/ post/shopee-tokopedia-e-commerceindonesia-q3-2019. Accessed on $8 / 9 / 2020$.

Aria, P. (2019). Tak Terusik Isu Blackpink, Shopee Cetak 12 Juta Transaksi Di Harbolnas. (https://katadata.co.id/ berita/2018/12/13/tak-terusik-isublackpink-shopee-cetak-12-jutatransaksi-di-harbolnas). Accessed on 3/12/2019.

Bungin, B. (2015). Komunikasi Pariwisata. Jakarta: Prenada Group

Cangara, H. H. (2013). Perencanaan Dan Strategi Komunikasi. Jakarta : PT Raja Grafindo Persada.

Chasanah, S.U. (2013). Pemasaran Sosial Kesehatan Edisi 1. Yogyakarta: Deeplublish.https://books.google. co.id/books?id=uAY3CAAAQBA$\mathrm{J} \&$ printse $\mathrm{c}=$ frontcover $\# \mathrm{v}=$ one page \&q\&f=false. Accessed on $3 / 12 / 2019$.

Effendi. (2006). Ilmu Komunikasi Teori dan Praktek. Bandung: PT. Remaja Rosdakarya.

Fajrian, H. (2019). Cetak Penjualan Rp. 54 T, Shopee E-Commerse Terpopuler Di Asia Tenggara. (https:// katadata.co.id/berita/2019/08/23/ cetak-penjualan-rp-54-t-shopeee-commerce-terpopuler-di-asiatenggara). Accessed on 2/12/2019

Fitriah, M. (2018). Komunikasi Pemasaran Melalui Desain Visual. Yogyakarta: Deepublish. https://books.google. co.id/books?id=-uZjDwAAQBAJ\& printsec $=$ frontcover $\# \mathrm{v}=$ onepage $\& \mathrm{q}$ $\& \mathrm{f}=$ false. Accessed on 3/12/2019.

Gita. Devi, \& Setyorini. Retno, (2016) PENGARUH BRAND AMBASSADOR TERHADAP
BRAND IMAGE PERUSAHAAN ONLINE ZALORA.CO.ID. e-Proceeding of Management : Vol.3, No.1 April 2016 | Page 620

Harahap, D.A. (2018). Perilaku Belanja Online Di Indonesia: Studi Kasus. Jurnal Riset Manajemen Sains Indonesia (JRMSI). Vol.9(2), pages. 193-213.

Hermawan, A. (2012). Komunikasi Pemasaran. Malang: Erlangga.

Hidayat, T. (2008). Panduan Membuat Toko Online dengan OSCommerce. Jakarta: Mediakita.

https://www.appannie.com/en/apps/ios/ app/shopee-indonesia-jual-beli/ Accessed on 8/9/2020.

https://www.appannie.com/en/apps/googleplay/app/com.shopee.id/. Accessed on $8 / 9 / 2020$.

Kartajaya, H. (2003). Marketing in Venus, Cetakan Kedua. Jakarta: PT. Gramedia Pustaka Utama.

Kemp, simon \& Moey. Sarah. (2019). DIGITAL 2019 SPOTLIGHT: ECOMMERCE IN INDONESIA. https://datareportal.com/reports/ digital-2019-ecommerce-inindonesia. Accessed on 8/9/2020.

Kennedy dan Soemanagara. (2006). Komunikasi Pemasaran, Strategi dan Taktik. Jakarta: Ghalia.

Kotler, P dan Amstrong. G. (1997). Prinsipprinsip Pemasaran, Edisi pertama. Jakarta: Erlangga.

Kotler, P dan Amstrong. G. (2008). PrinsipPrinsip Pemasaran, Edisi kedua belas. Jakarta: Erlangga

Kotler, Philip dan Keller, Kevin Lane. (2009). Marketing Management 13th ed. Prentice Hall, Pearson Educational International.

Kotler, P dan Keller. K.L. (2009). Manajemen Pemasaran, Edisi Ke Tiga Belas Jilid 1 Terjemahan. Jakarta: Erlangga.

Kurniawan, S. (2019). 6 Trend Perdagangan Digital 2019. (https://www.cnnindonesia.com/ teknologi/20190128133714-185$364403 / 6$-trend-perdagangandigital-2019). Accessed on 2/12/2019.

Larasati, R.A. (2019). Harbolnas, Shopee 
raih omzet 1,3 Triliun dalam waktu 24 jam. (https://money.kompas. com/read/2019/12/13/144244026/ harbolnas-shopee-raih-omzet-rp13-triliun-dalam-waktu-24-jam). Accessed on 23/7/2020.

Laudon, K.C, \& Traver. C.G. (2013). E-Commerce 2014: Business, Technology, Society, Tenth Edition. Prentice-Hall, Inc.

Lestari, H. Sunarti. Bafadhal.A.S. (2019). Pengaruh Brand Ambassador Dan Korean Wave Terhadap Citra Merek Serta Dampaknya Pada Keputusan Pembelian (Survei Online Pada Konsumen Innisfree Di Indonesia Dan China). Vol.66(1).

Meranti, Estu. (2019). Gfriend Meriahkan Panggung Shopee 11.11 Big Sale. https://marketeers.com/gfriendmeriahkan-panggung-shopee-11-11big-sale/). Diunduh pada 2 Desember 2019, pukul 16.00 WIB.

Noviyanti, K.A.P. (2017). Strategi Branding Melalui Penggunaan Brand Ambassador Di PT Kereta Api Indonesia (Persero) Kantor Pusat Bandung (Studi Kasus St 12 Sebagai Brand Ambassador). Vol.4(3), pages 3368.

Pudjiastuti, W. (2016). Social marketing: strategi jitu mengatasi masalah so- sial di Indonesia edisi ertama. Jakarta: Yayasan Pustaka Obor Indonesia. https://books.google. co.id/books?id=18BEDAAAQ$\mathrm{BAJ} \&$ printse $\mathrm{c}=$ frontcover $\# \mathrm{v}=\mathrm{O}-$ nepage \&q\&f=false. Accessed on $3 / 12 / 2019$

Purba, A. (2006). Pengantar Ilmu Komunikasi. Medan: Pustaka Bangsa Press.

Raswen, R.N. (2019). Pengaruh Brand Ambassador Blackpink Terhadap Citra Perusahaan Shopee Pada Mahasiswi Di Uin Suska Riau. Vol.6(2).

Royan, F.M. ( 2005). Marketing Celebrities. Jakarta: PT. Elex Media Komputindo.

Shimp, T.A. (2003). Periklanan dan Promosi. Jakarta: Erlangga.

Tjioptono, F. (1997). Strategi Pemasaran, Edisi Pertama. Yogyakarta: Andi.

Ulya, F.N. (2019). Gaet Blank Pink Dan Christiano Ronaldo, Apa Alasan Shopee? (https://money.kompas. $\mathrm{com} / \mathrm{read} / 2019 / 09 / 06 / 060300426 /$ gaet-blackpink-dan-ronaldo-jadibrand-ambassador-apa-alasanshopee-?page=all). Accessed on 2/12/2019.

Utomo, S.S. (2013). Komunikasi Pemasaran Sosial Terhadap Kesadaran Hidup Sehat Peternak Di Kecamatan Selo Boyolali. Vol.11(1), pages. 59-67. 